\title{
In Vivo Chemiluminescent Imaging Agents for Nitroreductase and Tissue Oxygenation
}

\author{
Jian Cao ${ }^{\dagger} \S$, James Campbell ${ }^{\#}$, Li Liü, Ralph P. Mason*, and Alexander R. Lippert ${ }^{\star}, \dagger, \S, \uparrow$ \\ tDepartment of Chemistry, Southern Methodist University, Dallas, TX, 75275-0314 \\ $\S$ Center for Drug Discovery, Design, and Delivery (CD4), Southern Methodist University, Dallas, \\ TX, 75275-0314 \\ "Center for Global Health Impact (CGHI), Southern Methodist University, Dallas, TX, 75275-0314. \\ \#Prognostic Imaging Research Laboratory (PIRL), Pre-clinical Imaging Section, Department of \\ Radiology, UT Southwestern Medical Center, Dallas, TX 75390-9058, USA
}

\begin{abstract}
Tissue oxygenation is a driving parameter of the tumor microenvironment and hypoxia can be a prognostic indicator of aggressiveness, metastasis, and poor response to therapy. Here we report a chemiluminescence imaging (CLI) agent based on the oxygen-dependent reduction of a nitroaromatic spiroadamantane 1,2-dioxetane scaffold. Hypoxia ChemiLuminescent Probe 2 (HyCL-2) responds to nitroreductase with 170-fold increase in luminescence intensity, with high selectivity for enzymatic reductase versus other small molecule reductants. HyCL-2 can image exogenous nitroreductase in vitro and in vivo in living mice and total luminescent intensity is increased by $\sim 5$-fold under low oxygen conditions. HyCL-2 is demonstrated to report on tumor oxygenation during oxygen challenge in H1299 lung tumor xenografts grown in a murine model as independently confirmed using multi-spectral optoacoustic tomography (MSOT) imaging of hemoglobin oxygenation.
\end{abstract}

\section{Graphical abstract}

\footnotetext{
*Corresponding Author alippert@smu.edu. Supporting Information

Experimental details, supplementary figures, and scanned spectra. The Supporting Information is available free of charge on the ACS Publications website. See DOI: 10.1039/b000000x/.

Author Contributions

The manuscript was written through contributions of all authors. All authors have given approval to the final version of the manuscript.

Conflict of Interest

The authors declare no competing financial interest.
} 


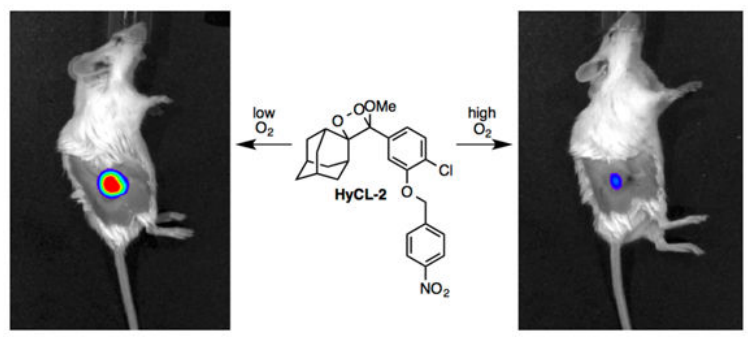

\section{Introduction}

Hypoxia refers to a physiological state of low tissue oxygenation and is a pathogenic characteristic of solid tumors that arises from absent or abnormal vasculature in the tumor microenvironment. ${ }^{1}$ Cancer cell populations respond to hypoxia by promoting survival pathways to suppress apoptosis ${ }^{2}$ and initiate angiogenesis, ${ }^{3}$ invasiveness, ${ }^{4}$ and metastasis. ${ }^{5}$ A key event initiated by low oxygen levels is the activation of the transcription factor hypoxia inducible factor 1 (HIF1). The HIF1-a subunit remains inactive through oxygendependent enzymatic hydroxylation of specific residues. ${ }^{6}$ In the absence of oxygen, however, HIF-1a dimerizes with the HIF-1 $\beta$ subunit and induces transcription of a host of proteins to support cancer cell survival. ${ }^{7}$ Activating prodrugs and imaging agents in a similar oxygen-dependent manner is an attractive strategy for imaging ${ }^{8}$ and treatment of cancer. ${ }^{9}$

Following this idea, the oxygen-dependent reduction of aromatic nitro groups by reductive enzymes, including xanthine oxidase, NADPH-cytochrome c reductases, and potentially cytosol DT diaphorase, aldehyde oxidase, and lipoyl dehydrogenase, ${ }^{10}$ is now a wellestablished method to target drugs, ${ }^{1 b, 9}$ imaging agents like FMISO, ${ }^{8,11}$ and immunohistochemical stains like pimonidazole ${ }^{12}$ to hypoxic areas. These targeting strategies have been cross-validated in comparison to other methods for direct measurement of tissue oxygenation including $\mathrm{pO}_{2}$ electrodes, ${ }^{13}$ magnetic resonance imaging (MRI) of ${ }^{19} \mathrm{~F}$-labeled perfluorocarbons, ${ }^{14}$ dynamic contrast enhanced MRI, ${ }^{15}$ tissue ${ }^{16}$ or blood ${ }^{17}$ oxygen level dependent (TOLD or BOLD) MRI, MRI-based oxygen imaging (MOXI), ${ }^{18}$ and multispectral optoacoustic (MSOT) imaging of hemoglobin and oxygenated hemoglobin. ${ }^{19}$ These techniques offer significant clinical opportunity, but require expensive instrumentation and highly trained experts that increase the cost and lower the throughput of these technologies.

Optical methods can provide a cheaper alternative to MRI and PET imaging methods. In recent years, small molecule fluorescence imaging agents have been developed that take advantage of the reduction of azobenzene, nitrobenzene, nitrofuran, and nitroimidazole functional groups to release a caged fluorescent dye. ${ }^{20}$ Despite progress towards in vivo hypoxia imaging with near-infrared emitting fluorophores, complications arising from autofluorescence, background, and light scattering remain problematic. Bioluminescent substrates for nitroreductase have been developed and have found application for imaging bacterial infection and cancer cells engineered to express bacterial nitroreductase. ${ }^{21}$ Although they display increased signal to background in comparison to fluorescent probes, these systems require expression or exogenous addition of luciferase and emit light through 
an oxygen-dependent process, complicating the development of caged luciferin probes for hypoxia imaging.

Considering these outstanding challenges for optical imaging of the tumor microenvironment, we have begun to develop chemiluminescent imaging (CLI) agents that can be applied in luciferase-null organisms for imaging a diverse set of parameters. ${ }^{22,23}$ Chemiluminescence results from the formation of an excited state product during an exothermic chemical reaction ${ }^{24}$ and is emerging as a useful preclinical in vivo imaging modality. ${ }^{25}$ Triggered chemiluminescence emission of spiroadamantane 1,2-dioxetanes has been extensively used for clinical assays ${ }^{26,27}$ and analyte sensing ${ }^{28}$ and has been recently demonstrated as an effective in vivo imaging modality for $\beta$-galactosidase ${ }^{22}$ and $\mathrm{H}_{2} \mathrm{~S}^{23}$ The high-energy 4-membered dioxetane ring can be sterically stabilized by synthetically appending spiroadamantane, ${ }^{26,28}$ fenchyl, ${ }^{29}$ or other frameworks, allowing for purification, synthetic manipulation, and long term storage. These systems can be designed such that a chosen chemical trigger will initiate an electron transfer cascade that leads to dioxetane ring cleavage. The reaction proceeds through a high-energy transition state that populates the excited state of the product, releasing the energy as light upon relaxation to the ground state. ${ }^{24}$ This energy can be further transferred to red-shifted dye molecules more suitable for biological imaging. ${ }^{30}$ Direct production of light from the energy of a chemical bond offers important advantages over fluorescence imaging by eliminating light excitation of a contrast agent, thereby providing reduced autofluorescence and light scattering. On the basis of these considerations and expanding the toolbox of chemiluminescent imaging methods for nitroreductase and hypoxia, we report the development of a spiroadamantane 1,2-dixoetanebased chemiluminescent platform, Hypoxia ChemiLuminescent Probes 1 and 2 (HyCL-1 and HyCL-2) for imaging tumor oxygenation in living animals.

\section{Results and Discussion}

A spiroadamantane 1,2-dioxetane scaffold was selected for the chemiluminescent-based probe design because it (1) displays instantaneous light production under biologically compatible conditions, (2) does not require the addition of oxidative species like hydrogen peroxide, and (3) the scaffold has demonstrated potential for in vivo imaging. ${ }^{22,23}$ Our strategy for designing these reaction-based chemiluminescent probes relies on tethering a para-nitrobenzyl moiety to a 1,2-dioxetane chemiluminescent scaffold via carbonate or ether linkage (Scheme 1). The nitrobenzene group is sensitive to nitroreductase enzymes and has been frequently used in prodrugs and hypoxia detection. The synthesis of HyCL-1 proceeds from the previously reported phenol $\mathbf{1}^{23}$ by dimethylaminopyridine-catalyzed coupling with the mixed $N$-hydroxysuccinimidyl carbonate 2 to form the enol ether precursor 3 (Scheme 2). For HyCL-2, the ether linkage of the precursor was prepared by a Mitsunobu reaction 31 between the phenol 1 and para-nitrobenzyl alcohol $\mathbf{4}$ to form the enol ether precursor 5 (Scheme 2). Both enol ethers $\mathbf{4}$ and $\mathbf{5}$ were subjected to [2+2] cycloaddition with photogenerated singlet oxygen using rose bengal as a sensitizer to provide HyCL-1 and HyCL-2 after purification by silica chromatography. Under hypoxic conditions or in the presence of nitroreductase, the para-nitrobenzyl moiety will be reduced, and then chemiluminescent emission will be initiated by self-immolative carbonate or ether cleavage to release the free phenolate bearing the 1,2-dioxetane (Scheme 1). The negatively charged 
phenol unit spontaneously triggers dioxetane cleavage and light emission through a series of electron transfer events. ${ }^{32}$

After obtaining HyCL-1 and HyCL-2, we proceeded to collect their absorption (Figure S1) and emission (Figure S2) spectra and measure their luminescent responses to bacterial nitroreductase in the presence of reduced nicotinamide adenosine dinucleotide (NADH) as a cofactor, a commonly employed model for reductase-activated probes. ${ }^{20}$ Nitroreductasedependent chemiluminescence was first evaluated in PBS (10 mM, pH 7.4) buffer containing 10\% Emerald II Enhancer using an F-7000 Hitachi spectrophotometer. The Emerald II Enhancer is a commercial aqueous solution that contains a proprietary cationic polymer and a dye with optical properties similar to fluorescein, with a peak absorption at $505 \mathrm{~nm}$ (Figure S1). Treatment of $10 \mu \mathrm{M}$ of HyCL-1 and HyCL-2 with $14 \mu \mathrm{g} / \mathrm{ml}$ nitroreductase, $0.4 \mathrm{mM}$ $\mathrm{NADH}$, and 10\% Emerald II Enhancer resulted in instantaneous and robust luminescent emission with two peaks centered at $455 \mathrm{~nm}$ and $545 \mathrm{~nm}$, which correspond to the emission wavelengths of the phenolate and the fluorescein-based Emerald II Enhancer, respectively (Figure S2). This light production increased over a course of 60 minutes (Figure S3) to provide a 5-fold and 170-fold luminescence turn-on for HyCL-1 and HyCL-2, respectively (Figure 1). We also found that the chemiluminescent emission enhancement was dose-dependent with respect to nitroreductase, demonstrating that both probes could be applied for sensitive nitrore-ductase detection. A linear response was found between 0-14 $\mu \mathrm{g} / \mathrm{mL}$ nitroreductase (Figure S4). This dose-dependence of light emission is observed immediately, revealing an advantage of using chemiluminescence probes for quick and direct nitroreductase detection without extensive incubation times. Chemiluminescent response data indicated that the ether-linked HyCL-2 displayed a much lower background emission (Figure 1b, red scan) compared with the carbonate linked HyCL-1 (Figure 1a, red scan). The reaction between HyCL-2, NADH, and NTR was analyzed by GC-MS, confirming the generation of 2-adamantanone (Figure S5) and methyl 4-chloro-3hydroxybenzoate (Figure S6), which provided fragmentation patterns that matched the spectra found in the NIST database. A molecular ion at $\mathrm{m} / \mathrm{z}=121$ was also observed that was assigned to 4-methylenecyclohexa-2,5-dien-1-one oxime (Figure S7). A high abundance peak at $\mathrm{m} / \mathrm{z}=123$ (aminobenzyl alcohol) was not observed. Taken together these observations are consistent with previous reports that the nitro group is initially reduced to a hydroxylamine, ${ }^{21 c, 33}$ followed by self-immolative cleavage to the chemiluminescent dioxetane phenolate.

We tested the selectivity of HyCL-1 and HyCL-2 against other biologically relevant molecules, particularly nucleophilic thiols, which are ubiquitous in physiological systems and involved in various redox cycles. The response of HyCL-1 or HyCL-2 $(10 \mu \mathrm{M})$ to 14 $\mu \mathrm{g} / \mathrm{mL}$ nitroreductase and $0.4 \mathrm{mM}$ NADH with $10 \%$ Emerald II Enhancer was monitored against other biological species in PBS buffer $(10 \mathrm{mM}, \mathrm{pH} 7.4)$, by adding $5 \mathrm{mM}$ reduced glutathione (GSH), $1 \mathrm{mM} \mathrm{L-cysteine} \mathrm{and} \mathrm{homocysteine,} \mathrm{or} 200 \mu \mathrm{M} \mathrm{H}_{2} \mathrm{~S}$, dithiothreitol (DTT), citrate, sodium metabisulfite, or L-ascorbic acid (Figure 2). We observed that HyCL-1 with a carbonate linker displayed poor selectivity against cellular thiols glutathione, cysteine, homocysteine, and DTT (Figure 2a). On the other hand, HyCL-2 with an ether linker showed excellent selectivity, and none of the other species tested displayed 
significant increases in luminescence intensity over the blank control (Figure 2b). When treated with nitroreductase $(14 \mathrm{ug} / \mathrm{mL})$ or NADH $(0.4 \mathrm{mM})$ alone, there was no increase in chemiluminescent emission over a blank control, indicating that both enzyme and cofactor are needed to induce a chemiluminescent response from HyCL-1 and HyCL-2. To better understand the response when treating HyCL-1 with cellular relevant thiol species and decipher the poor selectivity of $\mathbf{H y C L - 1}$, this probe was treated with cysteine and the reaction progress was monitored via ${ }^{1} \mathrm{H}$ NMR (Figure S8). This experiment provided two salient observations: 1 . The peak at $5.38 \mathrm{ppm}$ corresponding to the $-\mathrm{CH}_{2}-$ methylene peak para to the nitro group rapidly disappeared within 5 minutes, to be replaced by a new peak at $5.32 \mathrm{ppm} ; 2$. The nitroaromatic peaks at $8.18 \mathrm{ppm}$ and $7.58 \mathrm{ppm}$ persist even after 25 hours of reaction time. The first observation is consistent with displacement of the phenol by the reaction of the thiol with the carbonate functional group, thereby initiating chemiluminescence. The second observation confirms the stability of the nitroaromatic group in the presence of cysteine. Taken together, these observations indicate that the ether linkage provides an improved response and selectivity for HyCL-2 over HyCL-1, making it a sensitive chemiluminescent agent for imaging enzymatic reductase activity without interferences from other biological nucleophiles or small molecule reductants.

After demonstrating that HyCL-2 had the ability to detect enzymatic reductase activity with high sensitivity and selectivity, we moved towards testing its ability for hypoxia detection using an in vitro model. In order to interrogate luminescence response to low oxygen conditions, we deoxygenated a solution of $10 \mathrm{mM}$ PBS (pH 7.4) containing 10\% Emerald II Enhancer by bubbling nitrogen gas through the solution for 60 minutes. We then compared the chemiluminescent response of HyCL-2 to nitroreductase under oxygen-free conditions and ambient air conditions (Figure 3). At 5, 10, and $12.5 \mu \mathrm{g} / \mathrm{mL}$ nitroreductase a significant increase in luminescence intensity was observed under low oxygen conditions with up to a 5 -fold increase at $12.5 \mu \mathrm{g} / \mathrm{mL}$ nitroreductase. A control experiment consisted of bubbling air through a solution of PBS and Emerald II Enhancer for 60 minutes before probe and enzyme incubation. No significant difference in luminescence emission was observed from the experiment performed under ambient conditions, confirming that the increased response is due to deoxygenation and not from a mechanical effect of the bubbling procedure (Figure S9). These important experiments demonstrate that the luminescent response of HyCL-2 depends sharply on the presence or absence of dissolved oxygen, a necessary trait for imaging tumor hypoxia.

Having well characterized the in vitro spectroscopy, we then proceeded to investigate the ability of HyCL-2 as a CLI agent for nitroreductase activity at physiological $\mathrm{pH}$ using an IVIS Spectrum. An opaque 96-well plate was loaded with $10 \mu \mathrm{M}$ HyCL-2, $0.4 \mathrm{mM} \mathrm{NADH}$ and $0,2.5,7.5,10,12.5 \mu \mathrm{g} / \mathrm{mL}$ nitroreductase in PBS buffer (pH 7.4) containing $10 \%$ Emerald II Enhancer. Imaging light production indicated a clear increase in luminescence intensity with increasing nitroreductase concentrations (Figure 4a). The emitted light displayed good linearity with increasing concentrations of nitroreductase (Figure 4b), demonstrating the ability of HyCL-2 to accurately and sensitively image reductase activity. Encouraged by the robust chemiluminescent light generated from the multi-well plate experiment, we next tested if light production from HyCL-2 would be sufficient for 
nitroreductase imaging in living animal tissue. Anesthetized SCID/BALB-C mice were administered subcutaneous injections on their back. On the upper back, a solution of HyCL-2, NADH, nitroreductase, and Emerald II Enhancer was injected (Figure 5a, NTR +NADH), and a vehicle control solution with HyCL-2 and no nitroreductase or NADH was injected on the lower back (Figure 5a, Vehicle). The injected area on the upper back displayed a dramatic increase in chemiluminescent emission compared with the vehicle injection without nitroreductase or NADH on the lower side (Figure 5b). These experiments show that HyCL-2 can function as an in vivo CLI agent for nitroreductase activity.

Finally, we interrogated the ability of HyCL-2 to visualize tissue oxygenation and hypoxia in human tumor xenograft models. H1299 lung tumors were grown subcutaneously on the flanks of SCID/BALB-C mice. Tumor oxygenation was adjusted using an oxygen challenge experiment, where mice breathe either air (21\% oxygen) or $100 \%$ oxygen for several minutes prior to and during imaging. A solution of HyCL-2 in PBS buffer ( $\mathrm{pH}$ 7.4) containing 10\% Emerald II Enhancer was injected intratumorally and then imaged using an IVIS Spectra. While breathing air (21\% oxygen), high chemiluminescence emission was observed (Figure 6a) that decayed over a period of 10 minutes. After allowing time for the agent to clear, the mice were again injected intratumorally with HyCL-2 in PBS buffer (pH 7.4) containing 10\% Emerald II Enhancer, but this time with the mice breathing $100 \%$ oxygen. In comparison, breathing $100 \%$ oxygen caused an attenuation of the chemiluminescent signal (Figure 6b). This indicates, in agreement with the in vitro experiment described in Figure 3, that HyCL-2 provides increased signal in low oxygenation conditions found in hypoxic tumors. In order to further support this claim, the same mice underwent the oxygen challenge experiment while the levels of hemoglobin $(\mathrm{Hb})$ and oxygen-bound hemoglobin $\left(\mathrm{HbO}_{2}\right)$ were determined by multi-spectral optoacoustic tomography (MSOT) imaging ${ }^{19}$ (Figure 7). Magnification of the tumor reveals low total hemoglobin in the tumor center, characteristic of a hypoxic core surrounded by blood vasculature. Comparison of the images of the mouse breathing 16\% oxygen (Figure 7a) to the images of the mouse breathing $100 \%$ oxygen (Figure $7 \mathrm{~b}$ ) shows a clearly observable increase in $\mathrm{HbO}_{2}$, consistent with the data collected by chemiluminescent imaging and providing a secondary confirmation. Taken together, these experiments provide a preliminary validation of the CLI agent HyCL-2 for imaging tumor hypoxia.

\section{Conclusions}

We have designed and synthesized two spiroadamantane 1,2-dioxetane chemiluminescent reaction-based imaging probes, HyCL-1 and HyCL-2, that display immediate light emission upon reacting with nitroreductase and $\mathrm{NADH}$ at physiological $\mathrm{pH}$. Due to our scaffold optimization, the ether linked chemiluminescent agent HyCL-2 responds to nitroreductase with $\sim 170$-fold increase in luminescence intensity compared to a blank control, largely due to a drastically reduced background of the more hydrolytically stable ether linkage. This ether linkage is also critical to achieving high selectivity, particularly towards abundant biological thiol species. HyCL-2 has been successively applied for detection of nitroreductase using spectrophotometers, and imaging nitroreductase in vivo using an IVIS Spectra instrument. Studies on the oxygen dependence of the 
chemiluminescence emission of HyCL-2 in vitro revealed increases in luminescence in the absence of oxygen, a result that was also observed during in vivo oxygen challenge experiments in human H1299 lung tumor xenografts grown on mice. Tumor hypoxia and changes in oxygenation during the oxygen challenge experiments were independently confirmed by MSOT imaging of hemoglobin and oxygenated hemoglobin as a technique to directly measure in vivo blood oxygen levels. While this application of MSOT is incapable of direct oxygen measurements in central tumor areas with no vasculature, it provides supportive and complementary data to the CLI experiments performed herein. It should be noted that similar CLI experiments on larger tumors failed to produce consistent results due to decay of light intensity with imaging depth and attempts at imaging hypoxia in cell culture models were complicated by technical challenges with adding chemiluminescence reagents in the absence of oxygen. Future work aims to solve these challenges by developing single component agents with increased light production and non-intensity based readouts that can more accurately report on parameters without the confounding variables of imaging depth and temporal dependence. With these caveats in mind, HyCL-2 can find application for optical monitoring of tumor oxygenation in well-controlled preclinical experiments. We further anticipate that these studies will contribute towards the generalized development of chemiluminescence as a robust in vivo imaging modality.

\section{Experimental section}

\section{Spectroscopic Measurements}

UV/Vis spectra were acquired on a Beckman-Coulter DU 800 Spectrometer (Beckman Coulter, Inc., Brea, CA). Chemiluminescent responses were acquired using a Hitachi F-7000 Fluorescence Spectrophotometer (Hitachi, Tokyo, Japan) using the luminescence detection module and setting emission wavelength to $545 \mathrm{~nm} .889 \mu \mathrm{L}$ of a $10 \mathrm{mM}$ PBS buffered to $\mathrm{pH}$ 7.4, $2 \mu \mathrm{L}$ of a 5 mM HyCL-1 or HyCL-2 in DMSO, $8 \mu \mathrm{L}$ of a $50 \mathrm{mM}$ NADH in $0.01 \mathrm{mM}$ $\mathrm{NaOH}$ solution, $1.4 \mu \mathrm{L}$ of nitroreductase from Escherichia coli (NTR) in DI- $\mathrm{H}_{2} \mathrm{O}(1 \mathrm{mg}$ NTR dissolved in $100 \mu \mathrm{L}$ DI- $\mathrm{H}_{2} \mathrm{O}, 10 \mathrm{mg} / \mathrm{mL}$ ), and $100 \mu \mathrm{L}$ Emerald II Enhancer (Life Technologies, Carlsbad, CA) were added to an Eppendorf tube and samples were shaken gently to assure mixing. The mixed solution was then transferred to a quartz cuvette (Starna, Atascadero, CA). Time scans were acquired using the time scan module 1 min after adding probes. For the dose-dependent response to nitroreductase, $10 \mu \mathrm{M}$ HyCL-1 and HyCL-2 were treated with $8 \mu \mathrm{L}$ of a $50 \mathrm{mM}$ NADH and $0,0.5,0.75,1.0,1.25,1.4 \mu \mathrm{L} 10 \mathrm{mg} / \mathrm{mL}$ nitroreductase and $20 \mathrm{~min}$ (Figure 1, S9) or $120 \mathrm{~min}$ (Figure S3) time scans were measured 1 min after adding probes. Selectivity for HyCL-1 and HyCL-2 was measured by monitoring the time-dependent chemiluminescent emission at $545 \mathrm{~nm}$. All assays were performed in 10 mM PBS buffered to pH 7.4 with 10\% Emerald II Enhancer. Further details can be found in the supporting information.

\section{In vitro deoxygenation experiments}

$10 \mathrm{mM}$ PBS buffer (pH 7.4) and Emerald II Enhancer were mixed with a ratio of 9 to 1 and $\mathrm{N}_{2}$ was bubbled through it for 60 minutes. The solution was then transferred into a capped cuvette by syringe, and HyCL-2, NADH, and nitroreductase were added into the cuvette using a syringe. Time scans were performed 1 min after adding nitroreductase. For 
deoxygenation experiments, PBS buffer (pH 7.4) and Emerald II Enhancer mixture was deoxygenated by bubbling $\mathrm{N}_{2}$ for 60 minutes, and then $889 \mu \mathrm{L}$ of this deoxygenated mixture was transferred into a capped cuvette by syringe, and later $2 \mu \mathrm{L}$ of a $5 \mathrm{mM} \mathrm{HyCL-2}$ in DMSO, $8 \mu \mathrm{L}$ of a $50 \mathrm{mM}$ NADH in $0.01 \mathrm{mM} \mathrm{NaOH}$ solution, $1.25 \mu \mathrm{L}$ of nitroreductase (10 $\mathrm{mg} / \mathrm{mL}$ ) were added into the cuvette using syringe. Time scans were performed $1 \mathrm{~min}$ after adding nitroreductase. The control experiment was carried out under ambient conditions without deoxygenation.

\section{In vitro chemiluminescent imaging}

Imaging was carried out with a Caliper Xenogen IVIS ${ }^{\circ}$ Spectrum (Perkin-Elmer, Santa Clara, CA) in black 96-well Costar ${ }^{\circledR}$ plates and all the images were analyzed using Living Image 3.1 software. $1 \mathrm{mM}$ HyCL-2 in DMSO, $2 \mathrm{mg} / \mathrm{mL}$ nitroreductase $(10 \mu \mathrm{L}$ from $1 \mathrm{mg}$ NTR/100 uL DI- $\mathrm{H}_{2} \mathrm{O}$ diluted to $50 \mu \mathrm{L}$ by adding $40 \mu \mathrm{L}$ DI- $\mathrm{H}_{2} \mathrm{O}$ ) and $50 \mathrm{mM}$ NADH in 0.01 mM NaOH solution were prepared prior to imaging. $176.4 \mu \mathrm{L}, 176.1 \mu \mathrm{L}, 175.9 \mu \mathrm{L}, 175.5 \mu \mathrm{L}$ 175.4 $\mu \mathrm{L}$ and 175.1 $\mu \mathrm{L}$ of $10 \mathrm{mM}$ PBS buffer ( $\mathrm{pH}$ 7.4) were added into wells from A1 to A6 in sequence, 1.6 $\mu \mathrm{L} \mathrm{NADH}$ was pipetted into each well and then different volume of nitroreductase solution $(0 \mu \mathrm{L}, 0.25 \mu \mathrm{L}, 0.5 \mu \mathrm{L}, 0.75 \mu \mathrm{L}, 1.0 \mu \mathrm{L}, 1.25 \mu \mathrm{L})$ were added into each well. $2 \mu \mathrm{L}$ HyCL-2 was injected into the mixture and $20 \mu \mathrm{L}$ Emerald II Enhancer was pipetted into each well, and imaging was performed 3.45 minutes after adding reagents into the 96 well plate using an open filter. All images were acquired with f-stop 1, medium binning, auto exposure and the chamber set to $37^{\circ} \mathrm{C}$.

\section{General animal protocols}

The UT Southwestern Institutional Animal Care and Use Committee approved these investigations under Animal Protocol Number (APN \#2009-0150). Hair was removed from area surrounding the tumor using Nair (Church \& Dwight Co, Inc, Ewing, NJ), but the skin was left unbroken before injection. Mice were anesthetized and maintained using inhalation of $1.6 \%$ isoflurane in $16 \%$ oxygen gas.

\section{In vivo $\mathrm{CLI}$ of nitroreductase}

A stock solution of $5 \mathrm{mM}$ HyCL-2 in DMSO, $1 \mathrm{mg}$ nitroreductase dissolved in $100 \mu \mathrm{L}$ DI$\mathrm{H}_{2} \mathrm{O}$ and $50 \mathrm{mM} \mathrm{NADH}$ in $0.01 \mathrm{mM} \mathrm{NaOH}$ solution were prepared in advance. A $30 \mu \mathrm{L}$ aliquot of this solution was taken out from a mixture of $437 \mu \mathrm{L} 10 \mathrm{mM}$ PBS, $4 \mu \mathrm{L}$ HyCL-2, $8 \mu \mathrm{L} \mathrm{NADH}, 1.25 \mu \mathrm{L}$ NTR and $50 \mu \mathrm{L}$ Emerald II Enhancer and images were acquired $30 \mathrm{sec}$ after administering subcutaneous injections to anesthetized (1.6\% isoflurane) SCID/BALB$\mathrm{C}$ mice. A vehicle control was conducted in the same way except replacing nitroreductase and $\mathrm{NADH}$ with $\mathrm{H}_{2} \mathrm{O}$ and $0.01 \mathrm{M} \mathrm{NaOH}$, respectively.

\section{In vivo CLI of hypoxia in tumor xenografts}

A $100 \mu \mathrm{L}$ solution was taken out from a mixture of $446 \mu \mathrm{L} 10 \mathrm{mM}$ PBS, $50 \mu \mathrm{L}$ Emerald II Enhancer and $4 \mu \mathrm{L} 5 \mathrm{mM}$ HyCL-2 and images were acquired immediately and every minute after administering intratumoral injections to H1299 lung tumor xenografts on mice while the animals breathed ambient air. A similar experiment was performed in the same mice, but while breathing $100 \%$ oxygen 5 minutes before injection and 1.6\% isoflurane and $98.4 \%$ 
oxygen throughout the course of the imaging experiment. These experiments were reproduced on two different mice $(\mathrm{n}=2)$. Tumor sizes were $9.9 \mathrm{~mm} \times 6.4 \mathrm{~mm} \times 5.5 \mathrm{~mm}$ and $9.5 \mathrm{~mm} \times 7.6 \mathrm{~mm} \times 6.0 \mathrm{~mm}$.

\title{
Multispectral optoacoustic tomography (MSOT)
}

A thin layer of ultrasound coupling gel provided contact with the membrane and the animal holder was placed in the imaging chamber of the MSOT 256-TF device (iThera Medical Gmbh, Munich, Germany). Multi-spectral optoacoustic tomography (MSOT) imaging was performed in a transaxial section through the center of the tumor using five wavelengths: $715,730,760,800$, and $850 \mathrm{~nm}$. Twenty frames per wavelength were acquired and averaged. Initially, the tumor region was imaged while breathing $16 \%$ oxygen, which was switched to $100 \%$ oxygen. A model-based reconstruction was used prior to multispectral processing to provide relative concentrations of oxyhemoglobin and deoxyhemoglobin. These experiments were reproduced on two different mice $(n=2)$.

\section{Supplementary Material}

Refer to Web version on PubMed Central for supplementary material.

\section{ACKNOWLEDGMENT}

\author{
This work was supported by Southern Methodist University (start-up funds to A.R.L), the Center for Drug Design, \\ Discovery, and Delivery (CD4 seed money to A.R.L.), and CPRIT RP120670-P3 (R.P.M). Imaging was facilitated \\ by the SW-SAIR, a Resource of the Simmons Cancer Center supported in part by NIH P30 1CA142543 and used an \\ IVIS Spectrum, which was purchased under NIH 1S10RR024757 and iThera MSOT purchased under S10 \\ OD018094. We thank Maciej Kukula of the Shimadzu Center for Advanced Analytical Chemistry at the University \\ of Texas at Arlington for acquiring high-resolution mass spectrometry data and Ramona Lopez for experimental \\ assistance. \\ Funding Sources \\ CPRIT RP120670-P3; NIH P30 1CA142543; 1S10RR024757 and S10 OD018094.
}

\section{REFERENCES}

(1). (a) Padhani AR, Krohn KA, Lewis JS, Alber M. Eur. Radiol. 2007; 17:861-872. [PubMed: 17043737] (b) Wilson WR, Hay MP. Nat. Rev. Cancer. 2011; 11:393-410. [PubMed: 21606941] (c) Brown JM, William WR. Nat. Rev. Cancer. 2004; 4:437-447. [PubMed: 15170446] (d) Chen Y, Hu L. Med. Res. Rev. 2009; 29:29-64. [PubMed: 18688784]

(2). Erler JT, Cawthorne CJ, Williams KJ, Koritzinsky M, Wouters BG, Wilson C, Miller C, Demonacos C, Stratford IJ, Dive C. Mol. Cell. Biol. 2004; 24:2875-2889. [PubMed: 15024076]

(3). Krock BL, Skuli N, Simon MC. Genes Cancer. 2011; 2:1117-1133. [PubMed: 22866203]

(4). Pennacchietti S, Michieli P, Galluzzo M, Mazzone M, Giordano S, Comoglio PM. Cancer Cell. 2003; 3:347-361. [PubMed: 12726861]

(5). Sullivan R, Graham CH. Cancer Metastasis Rev. 2007; 26:319-331. [PubMed: 17458507]

(6). Maxwell PH. Cell Cycle. 2004; 3:156-159. [PubMed: 14712080]

(7). Semenza GL. Nat. Rev. Cancer. 2003; 3:721-732. [PubMed: 13130303]

(8). Krohn KA, Link JM, Mason RP. J. Nucl. Med. 2008; 49:129S-148S. [PubMed: 18523070]

(9). (a) Xu G, McLeod HL. Clin. Cancer Res. 2001; 7:3314-3324. [PubMed: 11705842] (b) Grove JI, Lovering AL, Guise C, Race PR, Wrighton CJ, White SA, Hyde EI, Searle PF. Cancer Res. 2003; 63:5532-5537. [PubMed: 14500391] (c) Denny WA. Curr. Pharm. Des. 2002; 8:1349-1361. [PubMed: 12052212] 
(10). (a) Wang CY, Behrens CC, Ichikawa M, Bryan GT. Biochem. Pharmacol. 1974; 23:3395-3404. [PubMed: 4155308] (b) Raleigh JA, Shum FY, Koziol DR, Saunders WM. Cancer Clin. Trials. 1980; 3:55-62. [PubMed: 6771029] (c) Josephy PD, Palcic B, Skarsgard LD. Biochem. Pharmacol. 1981; 30:849-853. [PubMed: 6894696] (d) Clarke ED, Goulding KH, Wardman P. Biochem. Pharmacol. 1982; 31:3237-3242. [PubMed: 6897358]

(11). (a) Nordsmark M, Loncaster J, Aquino-Parsons C, Chou SC, Ladekarl M, Havsteen H, Lindegaard JC, Davidson SE, Varia M, West C, Hunter R, Overgaard J, Raleigh JA. Radiother. Oncol. 2003; 67:35-44. [PubMed: 12758238] (b) Bryant DW, McCalla DR, Leeksma M, Laneuville P. Can. J. Microbiol. 1981; 27:81-86. [PubMed: 7011517] (c) Bryant C, DeLuca M. J. Biol. Chem. 1991; 266:4119-4125. [PubMed: 1999405] (d) Koder RL, Miller AF. Biochim. Biophys. Acta. 1998; 1387:395-405. [PubMed: 9748656]

(12). Prekeges JL, Rasey JS, Grunbaum Z, Krohn KH. Biochem. Pharmacol. 1991; 42:2387-2395. [PubMed: 1764122]

(13). Doll CM, Milosevic M, Pintille M, Hill RP, Fyles AW. Int. J. Radiat. Oncol. Biol. Phys. 2003; 55:1239-1246. [PubMed: 12654433]

(14). (a) Mason RP, Shukla HP, Antich PP. Magn. Reson. Med. 1993; 29:296-302. [PubMed: 8450738] (b) Zhao D, Jiang L, Mason RP. Methods Enzymol. 2004; 386:378-418. [PubMed: 15120262]

(15). (a) Cooper RA, Carrington BM, Loncasters JA, Todd SM, Davidson SE, Logue JP, Luthra AD, Jones AP, Stratford I, Hunter RD, West CML. Radiother. Oncol. 2000; 57:53-59. [PubMed: 11033189] (b) Jiang L, Zhao D, Constantinescu A, Mason RP. Magn. Reson. Med. 2004; 51:953-960. [PubMed: 15122677]

( 16 ). (a) Matsumoto K, Bernardo M, Subramanian S, Choyke P, Mitchell JB, Krishna MC, Lizak MJ. Magn. Reson. Med. 2006; 56:240-246. [PubMed: 16795082] (b) O'Connor JPB, Naish JH, Parker GJ, Waterton JC, Watson Y, Jayson GC, Buonaccorsi GA, Cheung S, Buckley DL, McGrath DM, West CML, Davidson SE, Roberts C, Mills SJ, Mitchell CL, Hope L, Ton NC, Jackson A. Int. J. Radiat. Oncol. Biol. Phys. 2009; 75:1209-1215. [PubMed: 19327904] (c) Hallac RR, Zhou H, Pidikiti R, Song K, Stojadinovic S, Zhao D, Solberg T, Peschke P, Mason RP. Magn. Reson. Med. 2014; 71:1863-1873. [PubMed: 23813468] (d) Beeman SC, Shui YB, Perez-Torres J, Engelbach JA, Ackerman JJH, Garbow JR. Magn. Reson. Med. 2015 doi: $10.1002 / \mathrm{mrm} 25821$.

(17). (a) Howe FA, Robinson SP, McIntyre DJO, Stubbs M, Griffiths JR. NMR Biomed. 2001; 14:497506. [PubMed: 11746943] (b) Hoskin PJ, Carnell DM, Taylor NJ, Smith RE, Stirling JJ, Daley FM, Saunders MI, Bentzen SM, Collins DJ, d'Arcy JA, Padhani AP. Int. J. Radiat. Oncol. Biol. Phys. 2007; 68:1065-1071. [PubMed: 17637389] (c) Zhao D, Pacheco-Torres J, Hallac RR, White D, Peschke P, Cerdán S, Mason RP. NMR Biomed. 2015; 28:937-947. [PubMed: 26058575]

(18). Zhang Z, Hallac RR, Peschke P, Mason RP. Magn. Reson. Med. 2014; 71:561-569. [PubMed: 23447121]

(19). (a) Lungu GF, Li ML, Xie X, Wang LV, Stoica G. Int. J. Oncol. 2007; 30:45-54. [PubMed: 17143511] (b) Shao Q, Morgounova E, Jiang C, Choi J, Bischof J, Ashkenazi S. J. Biomed. Opt. 2013; 18:076019. [PubMed: 23877772] (c) Gerling M, Zhao Y, Nania S, Norberg KJ, Verbeke CS, Englert B, Kuiper RV, Bergström Å, Hassan M, Neesse A, Löhr JM, Heuchel RL. Theranostics. 2014; 4:604-613. [PubMed: 24723982] (d) Rich LJ, Seshadri M. Radiology. 2015; 275:110-118. [PubMed: 25423146]

(20). (a) Kiyose K, Hanaoka K, Oushiki D, Nakamura T, Kajimura M, Suematsu M, Nishimatsu H, Yamane T, Terai T, Hirata Y, Nagano T. J. Am. Chem. Soc. 2010; 132:15846-15848. [PubMed: 20979363] (b) Cui L, Zhong Y, Zhu W, Xu Y, Du Q, Wang X, Qian X, Xiao Y. Org. Lett. 2011; 13:928-931. [PubMed: 21268631] (c) Okuda K, Okabe Y, Kadonosono T, Ueno T, Youssif BGM, Kizaka-Kondoh S, Nagasawa H. Bioconjugate Chem. 2012; 23:324-329.(d) Takahashi S, Piao W, Matsumura Y, Komatsu T, Ueno T, Terai T, Kamachi T, Kohno M, Nagano T, Hanaoka K. J. Am. Chem. Soc. 2012; 134:19588-19591. [PubMed: 23157219] (e) Guo T, Cui L, Shen J, Zhu W, Xu Y, Qian X. Chem. Commun. 2013; 49:10820-10822.(f) Piao W, Tsuda S, Tanaka Y, Maeda S, Liu F, Takahashi S, Kushida Y, Komatsu T, Ueno T, Terai T, Nakazawa T, Uchiyama M, Morokuma K, Nagano T, Hanaoka K. Angew. Chem. Int. Ed. 2013; 52:13028-13032.(g) Evans SM, Kim K, Moore EC, Uddin MI, Capozzi ME, Craft JR, Sulikowski GA, Jayagopal A. Bioconjugate Chem. 2014; 25:2030-2037.(h) Yuan J, Xu Y, Zhou N, Wang R, Qian X, Xu Y. 
RSC Adv. 2014; 4:56207-56210.(i) Li Z, Li X, Gao X, Zhang Y, Shi W, Ma H. Anal. Chem. 2013; 85:3926-3932. [PubMed: 23506563] (j) Li Z, He X, Wang Z, Yang R, Shi W, Ma H. Biosens. Bioelectron. 2015; 63:112-116. [PubMed: 25064818] (j) Xu J, Sun S, Li Q, Yue Y, Li Y, Shao S. Analyst. 2015; 140:574-581. [PubMed: 25422882] (k) Li Y, Sun Y, Li J, Su Q, Yuan W, Dai Y, Han C, Wang Q, Feng W, Li F. J. Am. Chem. Soc. 2015; 137:6407-6416. [PubMed: 25923361] (1) Bae J, McNamara LE, Nael MA, Mahdi F, Doerksen RJ, Bidwell GL III, Hammer NI, Jo S. Chem. Commun. 2015; 15:12787-12790.

(21). (a) Wong RHF, Kwong T, Yau K, Au-Yeung HY. Chem. Commun. 2015; 51:4440-4442.(b) Vorobyeva AG, Stanton M, Godinat A, Lund KB, Karateev GG, Francis KP, Allen E, Gelovani JG, McCormack E, Tangney M, Dubikovskaya EA. PLoS One. 2015; 10:e0131037. [PubMed: 26110789] (c) Porterfield WB, Jones KA, McCutcheon DC, Prescher JS. J. Am. Chem. Soc. 2015; 137:8656-8659. [PubMed: 26098396]

(22). Liu L, Mason RP. PLoS One. 2010; 5:e12024. [PubMed: 20700459]

(23). Cao J, Lopez R, Thacker JM, Moon JY, Jiang C, Morris SNS, Bauer JH, Tao P, Mason RP, Lippert AR. Chem. Sci. 2015; 6:1979-1985. [PubMed: 25709805]

(24). Ciscato LFML, Augusto FA, Weiss D, Bartoloni FH, Bastos EL, Albrecht S, Brandl H, Zimmermann T, Baader WJ. ARKIVOC. 2012; 3:391-430.

(25). (a) Lee D, Khaja S, Velasquez-Castano CJ, Dasari M, Sun C, Petros J, Taylor WR, Murthy N. Nat. Mater. 2007; 6:765-769. [PubMed: 17704780] (b) Baumes JM, Gassenmith JJ, Giblin J, Lee JJ, White AG, Culligan WJ, Leevy WM, Kuno M, Smith BD. Nat. Chem. 2010; 2:1025-1030. [PubMed: 21107365] (c) Tseng JC, Bailey D, Tupper T, Kung AL. Mol. Imaging Biol. 2014; 16:478-487. [PubMed: 24510470] (e) Shuhendler AJ, Pu K, Cui L, Uetrecht JP, Rao J. Nat. Biotechnol. 2014; 32:373-380. [PubMed: 24658645]

(26). Bronstein, IY.; Edwards, B.; Sparks, AL. U.S. Patent 5,538,847. filed May 7, 1993, and issued July 23, 1996

(27). (a) Schaap AP, Gagnon SD. J. Am. Chem. Soc. 1982; 104:3504-3506.(b) Schaap AP, Chen TS, Handley RS, DeSilva R, Giri BP. Tetrahedron Lett. 1987; 28:1155-1158.(c) Ciscato LFML, Weiss D, Beckert R, Baader WJ. J. Photochem. Photobiol. A. 2011; 218:41-47.(d) Matsumoto M, Watanabe N. Bull. Chem. Soc. Jpn. 2005; 78:1899-1920.(e) Watanabe N, Kino H, Ijuin HK, Yamada M, Matsumoto M. Tetrahedron. 2012; 68:6079-6087.

(28). (a) Sabelle S, Renard PY, Pecorella K, de Suzzoni-Dézard S, Créminon C, Grassi J, Mioskowski C. J. Am. Chem. Soc. 2002; 124:4874-4880. [PubMed: 11971738] (b) Richard JA, Jean L, Romieu A, Massonneau M, Noack-Fraissignes P, Renard PY. Org. Lett. 2007; 9:4853-4855. [PubMed: 17939676] (c) Koci J, Grandclaude V, Massonneau M, Richard JA, Romieu A, Renard PY. Chem. Commun. 2011; 47:6713-6715.(d) Turan IS, Akkaya EU. Org. Lett. 2014; 16:16801683. [PubMed: 24605965]

(29). Ciscato LFML, Weiss D, Beckert R, Baader WJ. J. Photochem. Photobiol. A. 2011; 128:41-47.

(30). (a) Han J, Jose J, Mei E, Burgess K. Angew. Chem. 2007; 119:1714-1717.(b) Park JY, Gunpat J, Liu L, Edwards B, Christie A, Xie XJ, Kricka LJ, Mason RP. Luminescence. 2014; 29:553-558. [PubMed: 24760607] (c) Bag S, Tseng JC, Rochford J. Org. Biomol. Chem. 2015; 13:17631767. [PubMed: 25500943]

(31). Renaudet O, Reymond JL. Org. Lett. 2004; 6:397-400. [PubMed: 14748602]

(32). (a) Schuster GB. Acc. Chem. Res. 1979; 12:366-373.(b) Adam W, Bronstein I, Trofimov AV, Vasil'ev RF. J. Am. Chem. Soc. 1999; 121:958-961.

(33). Lee MK, Williams J, Twieg RJ, Rao J, Moerner WE. Chem. Sci. 2013; 4:220-225. [PubMed: 23894694] 

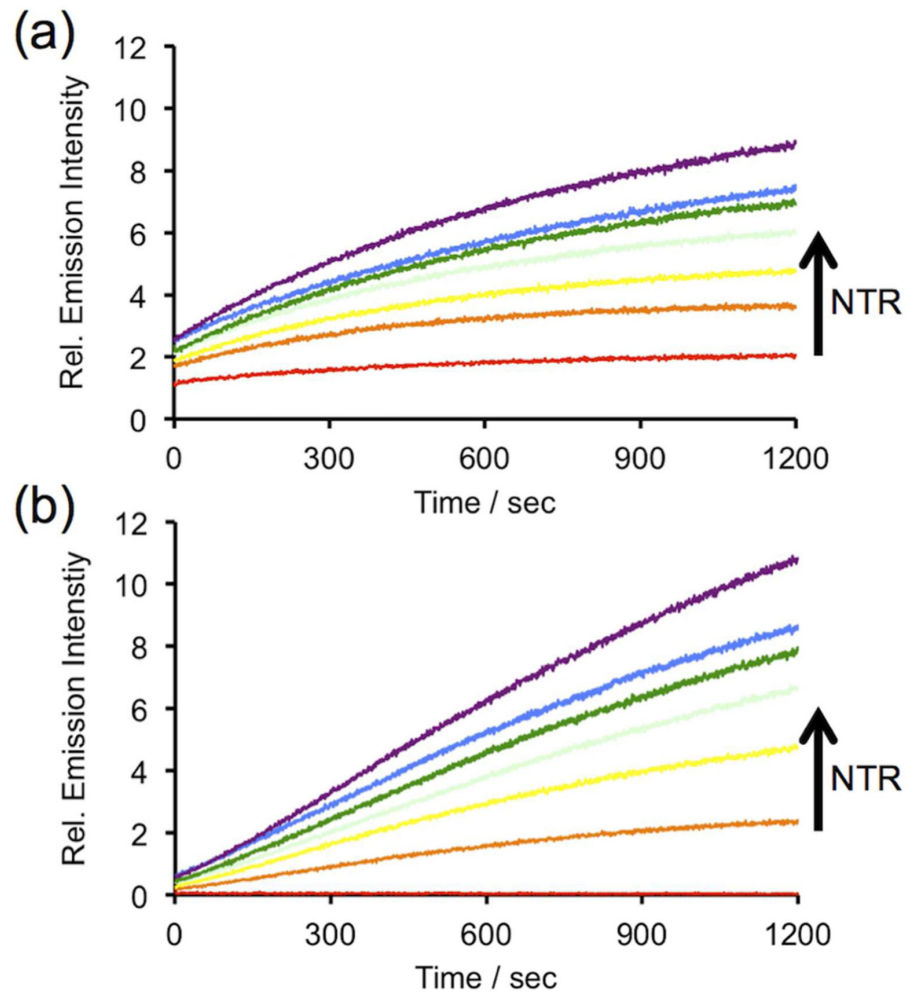

Figure 1.

Time scans of the chemiluminescent emission at $545 \mathrm{~nm}$ from (a) $10 \mu \mathrm{M}$ HyCL-1 and (b) 10 $\mu \mathrm{M} \mathrm{HyCL-2}$ and $0,2.5,5,7.5,10,12.5,14 \mu \mathrm{g} / \mathrm{mL}$ nitroreductase (NTR) in the presence of $0.4 \mathrm{mM}$ NADH in $10 \mathrm{mM}$ PBS buffer (pH 7.4) containing 10\% Emerald II Enhancer. 

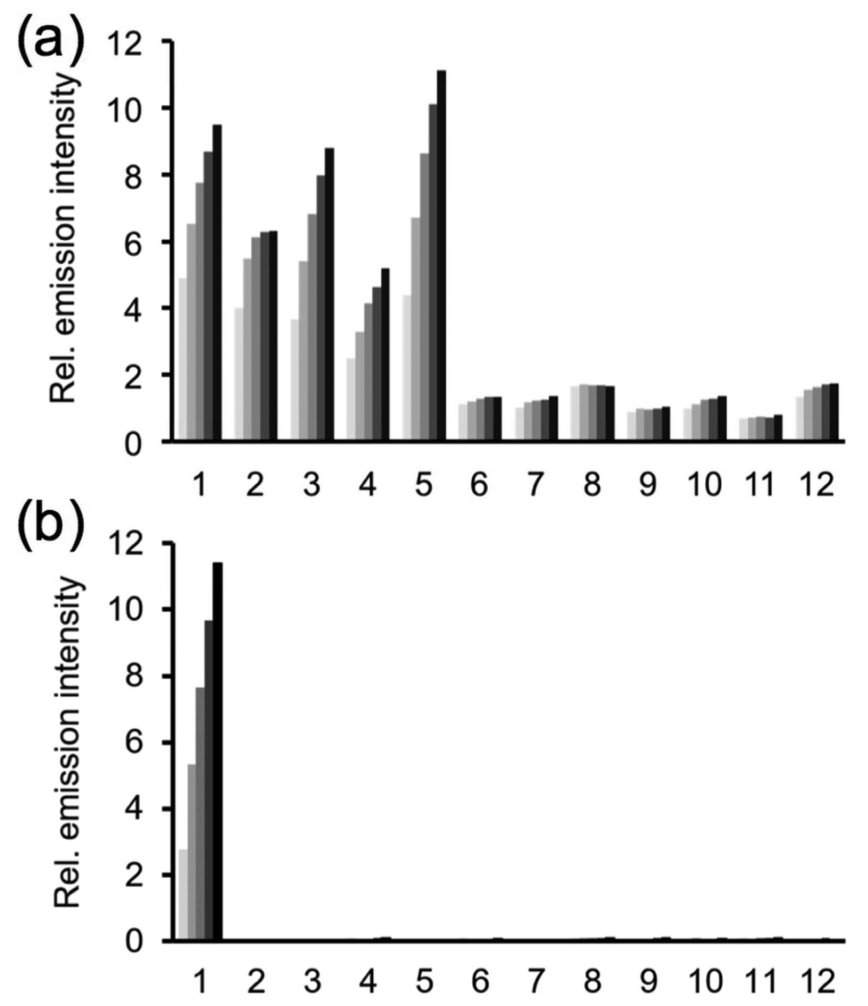

Figure 2.

Chemiluminescent responses of (a) $10 \mu \mathrm{M}$ HyCL-1 and (b) $10 \mu \mathrm{M}$ HyCL-2 to biologically relevant analytes in $10 \mathrm{mM}$ PBS buffer ( $\mathrm{pH}$ 7.4) containing 10\% Emerald II Enhancer. Bars represent chemiluminescent emission at $545 \mathrm{~nm}$ and 4, 8, 12, 16, $20 \mathrm{~min}$ after addition of reducing agents. Data shown are for $5 \mathrm{mM}$ glutathione, $1 \mathrm{mM}$ cysteine and homocysteine, and $200 \mu \mathrm{M}$ for other reducing agents. (1) NTR and NADH; (2) glutathione; (3) L-cysteine; (4) homocysteine; (5) DTT; (6) NTR; (7) NADH; (8) $\mathrm{H}_{2} \mathrm{~S}$; (9) citrate; (10) $\mathrm{Na}_{2} \mathrm{~S}_{2} \mathrm{O}_{5}$; (11) Lascorbic acid; (12) blank. 


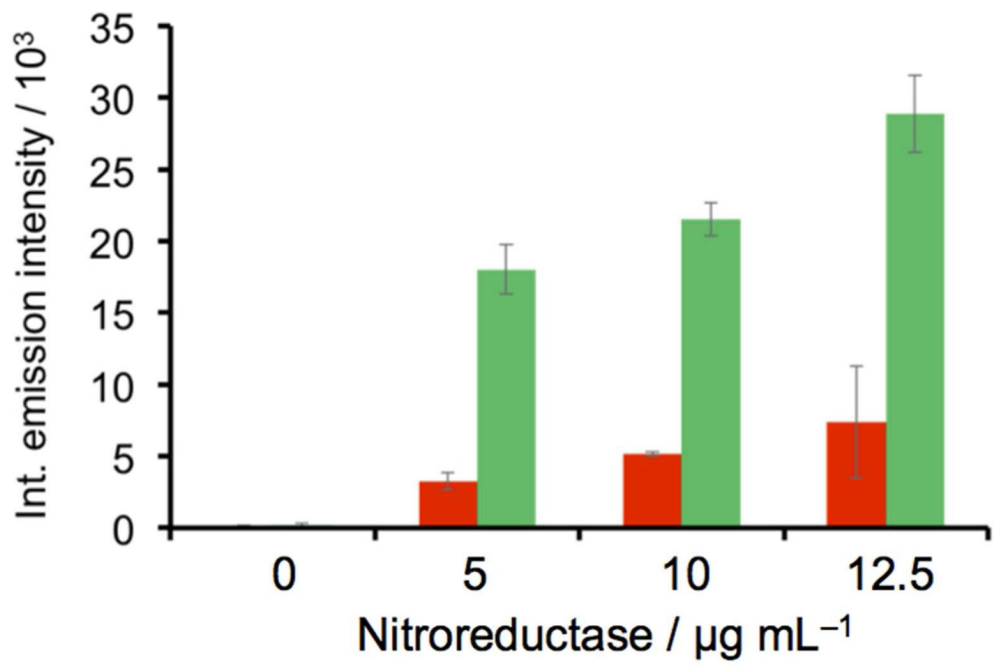

Figure 3.

Integrated chemiluminescent emission in the presence (red bars) and absence (green bars) of oxygen over $20 \mathrm{~min}$ of $10 \mu \mathrm{M}$ HyCL-2 and $0,5,10$, and $12.5 \mu \mathrm{g} \mathrm{mL}{ }^{-1}$ NTR in $10 \mathrm{mM}$ PBS buffer ( $\mathrm{pH} 7.4)$ containing $0.4 \mathrm{mM}$ NADH and $10 \%$ Emerald II Enhancer $(\mathrm{n}=3)$. Error bars are \pm S.D. 
(a)

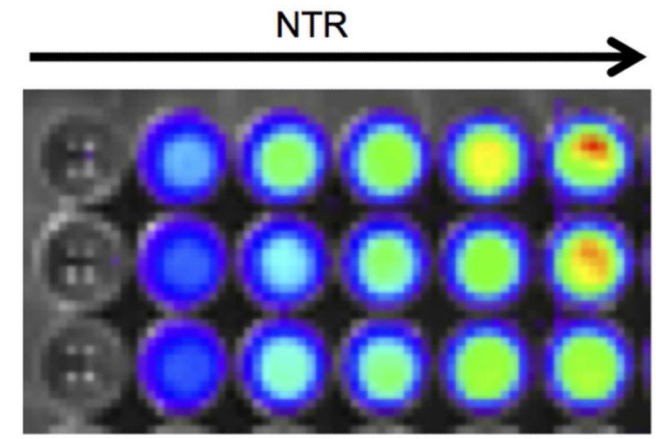

(b)

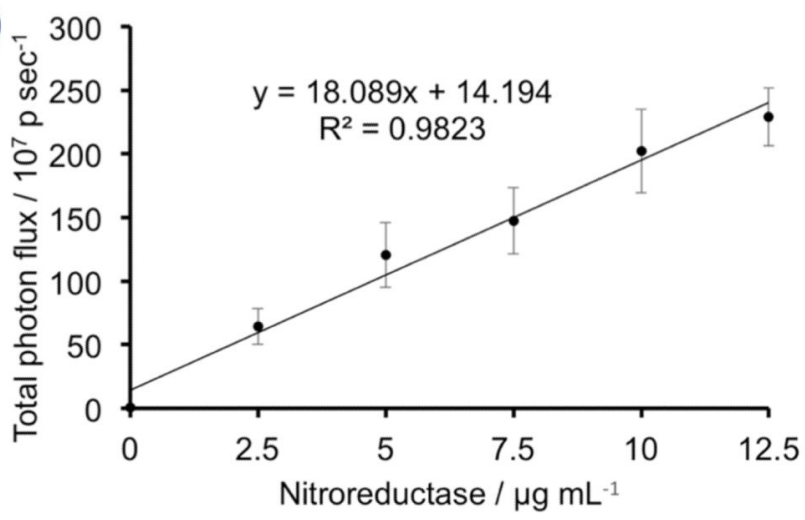

Figure 4.

Imaging of nitroreductase using HyCL-2. (a) Images 30 min after adding $10 \mu \mathrm{M}$ HyCL-2 to $0,2.5,5,7.5,10,12.5 \mu \mathrm{g} / \mathrm{mL}$ NTR in $10 \mathrm{mM}$ PBS buffer ( $\mathrm{pH} 7.4$ ) containing $0.4 \mathrm{mM}$ NADH and 10\% Emerald II Enhancer ( $n=3$ wells). (b) Quantification of total photon flux of the images in (a) ( $n=3$ wells). Error bars are \pm S.D. 
(a)

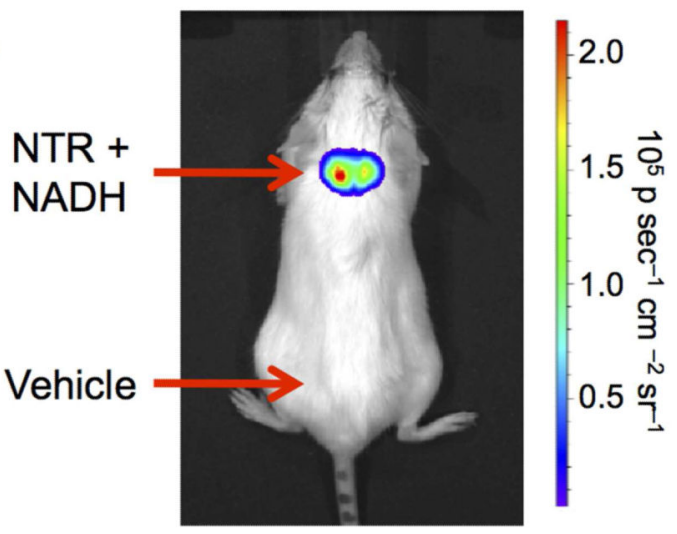

(b)

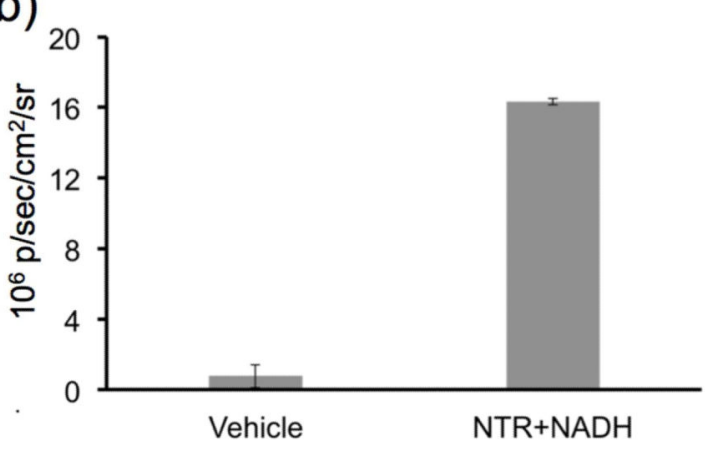

Figure 5.

In vivo nitroreductase imaging. (a) Image of a living SCID/BALB-C mouse $30 \mathrm{~s}$ after administering subcutaneous injections of $30 \mu \mathrm{L}$ of a solution containing $40 \mu \mathrm{M}$ HyCL-2, 14 $\mu \mathrm{g} \mathrm{mL}{ }^{-1}$ NTR, $0.4 \mathrm{mM}$ NADH, and 10\% Emerald II Enhancer in $10 \mathrm{mM}$ PBS (pH 7.4). In the vehicle control nitroreductase and $\mathrm{NADH}$ were replaced with $\mathrm{H}_{2} \mathrm{O}$ and $0.01 \mathrm{M} \mathrm{NaOH}$. (b) Quantification of biological replicates $(n=2$ mice). Error bars are high and low values of the two replicates. 

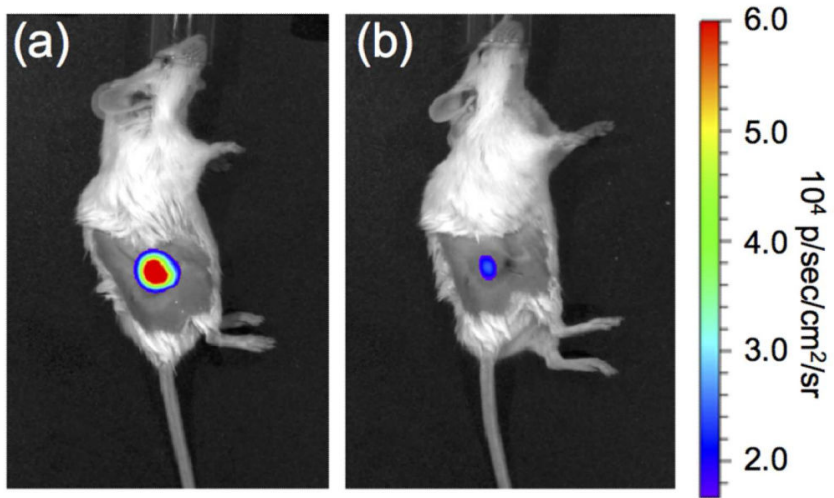

(c)

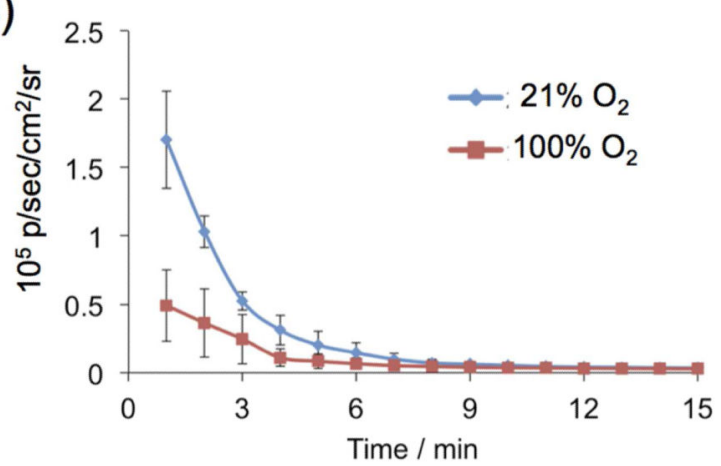

Figure 6.

Images of living H1299 lung tumor xenografts on SCID/BALB-C mice 1.5 min after administering intratumoral injections of $100 \mu \mathrm{L} 40 \mu \mathrm{M}$ HyCL-2 and 10\% Emerald II Enhancer in $10 \mathrm{mM}$ PBS (pH 7.4) while breathing (a) air or (b) $100 \%$ oxygen. (c) Quantification of biological replicates $(\mathrm{n}=2$ mice). Error bars are high and low values of the two replicates. 

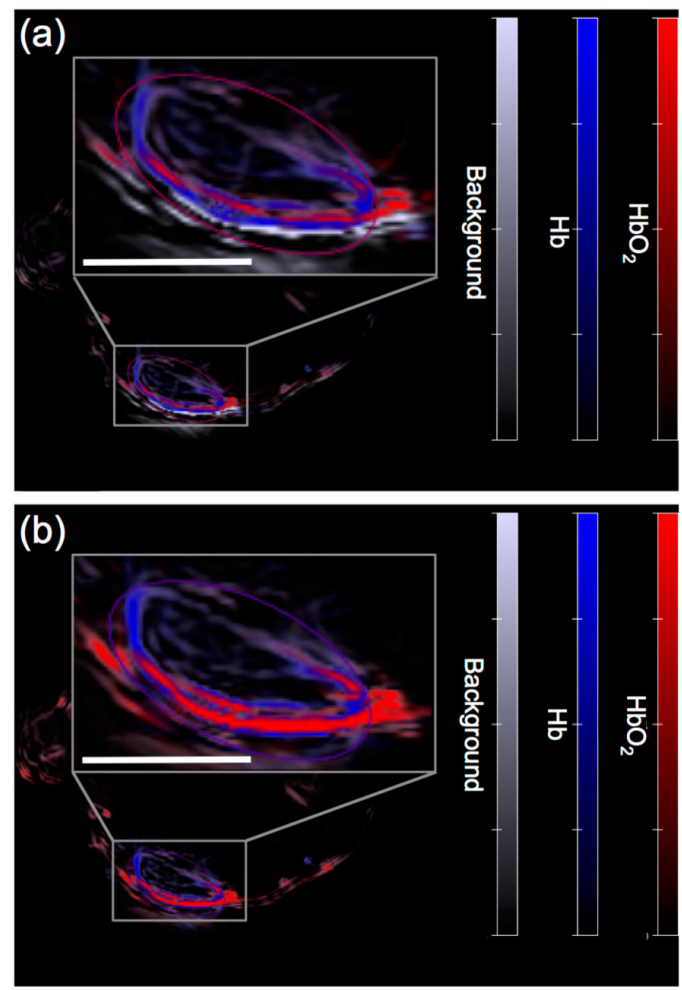

Figure 7.

Multi-spectral optoacoustic tomography (MSOT) images of a living H1299 bearing SCID/ BALB-C mouse while breathing (a) 16\% oxygen or (b) $100 \%$ oxygen. Scale bars are $3 \mathrm{~mm}$. 

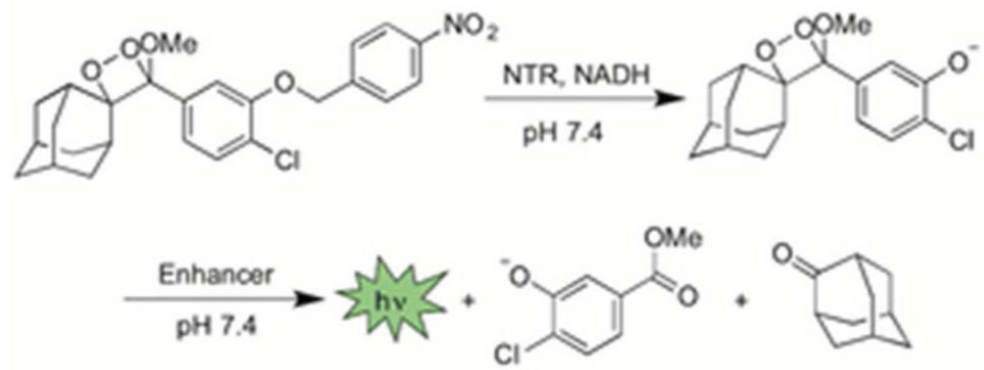

Scheme 1.

Spiroadamantane 1,2-dioxetanes for chemiluminescent nitroreductase (NTR) detection at neutral pH. 


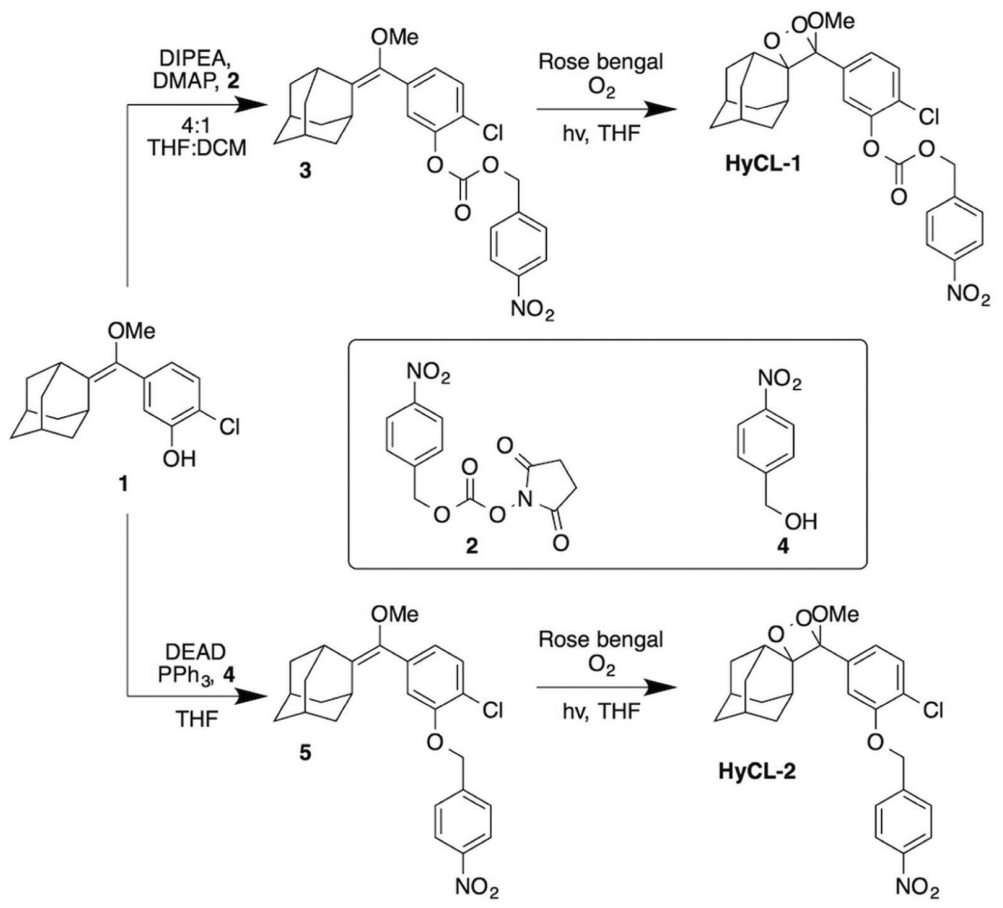

Scheme 2.

Synthesis of HyCL-1 and HyCL-2. 